\title{
FINANCIAL POLICIES AND THE AGGREGATE PRODUCTIVITY OF THE CAPITAL STOCK: EVIDENCE FROM DEVELOPED AND DEVELOPING ECONOMIES
}

\author{
Philip Arestis \\ Levy Economics Institute \\ Panicos Demetriades \\ University of Leicester \\ and \\ Bassam Fattouh \\ CeFiMS, SOAS
}

\section{INTRODUCTION}

The creation of a single global financial market is perhaps the most important component of the globalization process. One important prerequisite for the creation of the global financial market is the harmonization of financial regulations between national financial markets. In terms of policy prescription, the harmonization of regulations has usually been perceived to be equivalent to dismantling controls on financial market activity. Thus, financial liberalization, which is aimed at removing regulations on financial market activity, has become a central part of the financial globalization process.

During the last two decades, financial systems all over the world have undertaken extensive financial liberalization programs. In the case of the EU, the creation of the European Common Market led to the abolition of all remaining controls in the late 1980s. For emerging market economies, financial liberalization programs were usually implemented with the encouragement of the World Bank and the IMF, in many cases as part of a broad structural adjustment program. Prior to the East Asian crisis, it was widely believed that these liberalization efforts would bring substantial benefits by enhancing the efficiency of the financial sector, especially in terms of allocating resources towards the most productive investment projects. However, the reality has been much more complex, especially given the informational asymmetries that accompany financial transactions of any kind. These asymmetries have meant that where prudential regulation has been weak, moral hazard-type problems

Philip Arestis: Levy Economics Institute, Blithewood, Annandale-on-Hudson, NY, 12504-5000. Email: p.arestis@levy.org

Eastern Economic Journal, Vol. 29, No. 2, Spring 2003 
resulted in excessive risk-taking by financial institutions or investors, which then led to financial fragility or banking crises.

While the medium-term costs of financial liberalization and greater integration into international financial markets in terms of heightened fragility of the financial system are now recognized, its longer-term benefits, albeit widely accepted, remain the subject of an ongoing debate. Earlier empirical literature, which attempted to capture these benefits by focusing on the cross-country relationship between the real interest rate and economic growth or the efficiency of investment [Gelb, 1989], is now believed to have been flawed. In this respect Stiglitz [1998] argues that these regressions suffer from simultaneity and mis-specification problems. Arestis and Demetriades [1997] reinforce these criticisms focusing on the causality and heterogeneity issues. On the basis of available empirical literature, it can safely be concluded that considerable scope remains for further research into the channels through which financial policies of various types, including financial liberalization, may affect economic performance.

This paper provides a comprehensive empirical assessment of the effects of financial policies, including financial liberalization, on the average productivity of capital in fourteen economies. A broad literature has established that the financial sector in an economy can be important in determining the average productivity of capital, itself being one of the main channels of economic growth. Specifically, the screening and monitoring of investment projects, in which the financial system routinely engages, are likely to help boost the efficiency of investment [Pagano, 1993]. A growing empirical literature in fact demonstrates that the development of the financial system has positive effects on (i) the long-run rate of economic growth or (ii) the volume or efficiency of investment [Fry, 1995]. However, the causal nature of this relationship is now known to exhibit considerable variation across countries [Demetriades and Hussein, 1996]. This indicates that institutional factors or policies may play a critical role in determining how the process of financial development affects economic growth [Arestis and Demetriades, 1997]. The importance of institutional factors is confirmed by Demirgüç-Kunt and Detragiache [1999], who demonstrate that institutional quality is inversely related to the incidence of financial fragility that usually follows episodes of financial liberalization. The relevance of financial liberalization policies is highlighted by Demetriades and Luintel [1996; 1997; 2001] and Arestis et al. [2002] who demonstrate that the direct effects of financial repression in some developing countries are much larger than, and in some instances opposite to, those emanating from changes in the real interest rate.

To assess the impact of financial policies on capital productivity, we constructed a new data set on financial policies. A summary of financial policies used to construct the new data set appears in the Appendix. These were collected either directly from central banks or from official publications for a period of forty years. This exercise itself constituted a major research effort. Specifically, we collected data from central banks on several types of financial restraints, including restrictions on interest rates and capital flows, reserve, and liquidity requirements and capital adequacy requirements. We estimate the effects of these policies on the aggregate productivity of the capital stock using modern econometric methods that exploit both the time-series 
and cross-section dimensions of our data set. We find that financial development has positive effects on productivity while the effects of financial policies vary considerably across countries. Our findings demonstrate that financial liberalization is a much more complex process than has been assumed by earlier literature and its effects on key macroeconomic aggregates are ambiguous.

\section{FINANCIAL POLICIES AND THE PRODUCTIVITY OF CAPITAL: CONCEPTUAL ISSUES}

There are valid reasons why financial policies, including financial restraints, can have important real effects, not only on financial development but also on the efficiency of investment and, ultimately, the productivity of the capital stock. To start with there are the seminal contributions of McKinnon [1973] and Shaw [1973], which predict that interest rate controls and directed credit programs impede the process of financial deepening, reducing both the volume and productivity of investment. These types of models also predict that financial liberalization policies have positive effects on the volume and efficiency of investment [Fry 1995; 1997]. In contrast, a growing literature emphasizes financial market imperfections, including asymmetric information and imperfect competition, that reaches conclusions contrary to the financial liberalization hypothesis [Stiglitz, 1994; Caprio, 1994; Hellman, Murdock and Stiglitz, 1996a; 2000].

Besides these macroeconomic approaches, additional models investigate the effects of financial regulation, especially capital adequacy requirements, on risk taking by banks [Kim and Santomero, 1988; Keeley and Furlong, 1990; Gennotte and Pyle, 1991]. While these models do not explore the wider macroeconomic implications of these types of policies, all the recent episodes of financial fragility (for example, Japan and East Asia) have vividly demonstrated that excessive risk-taking by financial institutions can trigger severe macroeconomic downturns.

The empirical literature on the effects of financial policies is still in its infancy. The banking literature tends to focus on the effects of capital adequacy on the behavior of U.S. banks [Shrieves and Dahl, 1992; Hancock, Laing and Wilcox, 1995; Peek and Rosengren, 1995]. The few macroeconometric studies that focus on a handful of Asian economies, reveal that the effects of financial restraints may be very large but vary considerably across countries [Demetriades and Luintel, 1997; Demetriades, Devereux and Luintel, 1998]. Cross-country growth regressions indicate that financial restraints, with perhaps the exception of controls on capital outflows, may hamper economic performance [Rossi, 1999].

In the rest of this section we explore the likely macroeconomic effects of four broad types of financial policies-interest rate restraints, restrictions on capital flows, reserve and liquidity requirements and capital adequacy requirements. Financial liberalization programs usually aim at removing or relaxing the first three types of restraints. The fourth policy was in many cases introduced independently from financial liberalization policies but has nevertheless been widely considered to be crucial in reducing the risks associated with banking. As a result it constituted an important ingredient of banking reforms, especially in the $1980 \mathrm{~s}$. 


\section{Interest Rate Restraints}

In McKinnon [1973] and Shaw's [1973] framework, interest rate restraints adversely affect the quality of investment by allowing low productivity projects to remain profitable. Hence, in this framework, interest rate liberalization, by improving the allocation of credit towards more productive projects, will positively affect the average productivity of capital. However, some authors have suggested that in the presence of information asymmetries, liberalization of interest rates may not necessarily lead to efficiency gains [Schiantarelli et al., 1994]. In the presence of implicit deposit insurance, interest rate liberalization may encourage banks to take excessive risks [McKinnon and Pill, 1997]. This form of moral hazard may manifest itself in loans to highly risky, even speculative, activities such as real estate acquisitions and stock purchases that may distort the allocation of resources away from productive activities [Caprio, 1994]. In such circumstances, interest rate liberalization will not only reduce the average productivity of capital but may also lead to an increase in bad debts. Equally important, financial liberalization, if accompanied by increased competition, may erode the franchise value of banks [Caprio and Summers, 1994]. This exacerbates the problems of moral hazard in the banking system and encourages looting behavior in banking, hence increasing the probability of financial crisis [Akerlof and Romer, 1993].

In contrast, some types of financial restraints, including interest rate ceilings, can in fact reduce the problems of moral hazard and adverse selection [Stiglitz, 1994]. In doing so, they may enhance the soundness of the domestic banking system, which in turn may result in better allocation of resources [Arestis and Demetriades, 1997]. Hellman et al. [1996a; 1996b; 2000], argue that "financial restraint" policies create rent opportunities in the financial sector, which enhance incentives for financial deepening. These ideas are applied to deposit mobilization, which is crucial to many developing countries. By limiting deposit rates at below competitive equilibrium rates, governments create rent opportunities, which the banking sector could utilize for what is termed "educational advertising campaign," a tool of non-price competition which facilitates the mobilization of deposits, thereby enhancing financial deepening in a system of low financial depth. The outcome of financial restraints under these conditions is shown to be superior than under a free market, laissez-faire system.

A related point is that interest rate restrictions generate scope for rationing credit in accordance to national priorities through directed credit programs. While in many countries directed credit programs failed to achieve efficiency gains, some governments have been successful in channeling credit towards projects with high social returns, which may have been unprofitable to finance with the higher interest rates that usually prevail in liberalized credit markets [Calomiris and Himmelberg, 1994]. For example, in some East Asian countries the willingness to adapt credit policies to changing circumstances and the use of contests based on export performance to guide direct credit programs are believed to have contributed significantly to the effectiveness of these programs [World Bank, 1993]. 


\section{Restrictions on Capital Inflows}

The impact of foreign investment restrictions on the average productivity of capital is expected to vary depending largely on the nature of the restrictions. Restrictions on foreign direct investment flows are likely to have a negative impact on the average productivity of capital. Other than the fact that they may deter foreign investors, reducing the flow of ideas and technology transfer, restrictions aimed at prohibiting capital from flowing to certain sectors may lead to a misallocation of resources. It is now widely recognized that there may be more costs associated with short-term capital inflows than benefits. While short-term capital inflows may, in principle, supplement domestic saving and lead to higher levels of investment and higher growth rates, this benefit is likely to be small in economies with already high saving and investment ratios. The recent financial crisis in East Asia has demonstrated that where it is not possible to invest short-term capital inflows in productive activities, they could end up creating asset price bubbles, especially when they are channelled into the stock market or the property market. During the early stages of this process capital inflows lead to unsustainable asset price increases, fuelling the euphoria of investors and leading to incorrect investment decisions (Arestis, Demetriades and Fattouh, 2001]. Relative price distortions and resource misallocations of this type are likely to impact the average productivity of capital negatively; consequently restrictions on short-term capital flows may well prevent this occurrence.

\section{Reserve and Liquidity Requirements}

Reserve and liquidity requirements are usually designed to ensure that banks are sufficiently liquid to be able to meet day-to-day withdrawals by depositors. Minimum reserve and liquidity requirements are particularly useful when money markets are not sufficiently deep or developed, which is frequently the case in developing countries. But even in developed markets, reserve and liquidity requirements can play a useful role, especially when there is imperfect information about a bank's solvency. In principle, a bank that is solvent, and may face an imbalance between short-term payments and short-term income, can borrow through the interbank market to close this liquidity gap. However, frequent liquidity shortages may create solvency constraints. As a result, wholesale banks may refuse to provide an illiquid bank with the necessary funds. Consequently, the illiquid bank may be forced to sell long-term assets at distress prices, lowering the value of its assets. Hence, what starts as a problem of liquidity may well be translated into a problem of insolvency [Dewatripont and Tirole, 1993].

In contrast, advocates of financial liberalization consider reserve and liquidity requirements as a tax on financial intermediation, which widens the spread between deposit and loan interest rate and reduces the size of the financial system [Fry, 1995]. Hence, the abolition of reserve requirements, by increasing the size of financial intermediation and removing the distortionary effects of the tax, is likely to result in a 
more efficient allocation of financial resources, which could help to increase the average productivity of capital. This argument is implicitly based on the assumption that government revenue from reserve and liquidity requirements is used unproductively, probably to finance government consumption. If these resources are instead used to finance productive public investment, this conclusion may not follow. Much of the literature on infrastructure, in fact, demonstrates that investment in public capital increases the productivity of private capital [Aschauer, 1989; Lynde and Richmond, 1993; Nadiri and Mamuneas, 1994; Demetriades and Mamuneas, 2000]. ${ }^{1}$ If this is the case, reserve and liquidity requirements may well enhance the average productivity of capital.

\section{Capital Adequacy Requirements}

Regulators expect capital adequacy requirements first to reduce bank insolvency risk or default, second to reduce the scope for moral hazard behavior by banks thereby containing their tendency to take excessive risks, and finally to reduce the losses of depositors in the event of bank failure [Wall and Peterson, 1996; Blum and Hellwig, 1995]. The theoretical literature is not unanimous about achieving the first and second objectives [Berger, Herring, and Szego, 1995]. Using a mean-variance framework, Kim and Santomero [1988] suggest that capital regulation may in fact increase a bank's portfolio risk and hence lead to an inefficient allocation of assets. Specifically, an involuntary reduction in leverage can be met by a change in the composition of a bank's portfolio towards more risky assets. Keeley and Furlong [1990] argue, however, that the mean variance approach is inadequate to address the impact of capital adequacy requirements. This is because the mean-variance framework fails to recognize that the bank does not have full liability and that the value of deposit insurance will increase as the bank's leverage increases. When the model is adjusted to take this feature into account, Keeley and Furlong [ibid.] show that higher capital requirements would always result in lower risk-taking on behalf of the bank. However, in a different approach that incorporates Keeley and Furlong's suggestion concerning the value of deposit insurance and under the assumption that bank investments are subject to decreasing returns, Gennotte and Pyle [1991] show that capital requirements increase the risk of banks' portfolios. This offsets the benefits from higher levels of capital, which may increase the probability of default and impair the efficiency of bank lending.

Capital requirements also have other unintended consequences, which may have adverse implications for the average productivity of capital. Blum and Hellwig [1995] develop a model in which capital requirements amplify macroeconomic fluctuations by increasing lending activity in good times and reducing it in bad times. Other studies have shown that capital adequacy ratios may contribute to a credit crunch by reducing the amount of new loans to businesses [Hancock et al., 1995]. Finally, others have argued that capital regulations may lead to allocative inefficiency by shifting the use of traditional bank loans to off-balance sheet assets [Berger et al., 1995]. 


\section{ECONOMETRIC METHODOLOGY}

\section{Model Specification}

Our methodology builds on recent work modelling the sources of productivity, ${ }^{2}$ and involves a number of empirical novelties. Instead of measuring total factor productivity as a residual, we estimate it directly by modelling its sources. To this end we assume that total factor productivity, among other things, can be ascribed to financial development and financial policies. Another empirical novelty is the utilization of recent econometric techniques that respect the time series properties of the data while at the same time exploiting the cross section dimension of the data set. Our method allows us to address the problem of inconsistent estimates in dynamic heterogeneous panels identified by Pesaran and Smith [1995].

We estimate the following equation, in which some of the variables are lagged one period to avoid possible simultaneity:

$$
\log \left(Y_{t} / K_{t}\right)=\beta_{0}+\beta_{1} \log K_{t-1}+\beta_{2} \log L_{t-1}+\beta_{3} \log F_{t-1}+\gamma Z_{t}+\epsilon_{t}
$$

where $Y, K$ and $L$ stand for output, capital, and employment respectively, $F$ is an indicator of financial development and $\boldsymbol{Z}$ is a vector of financial sector policies, including interest rate restraints, reserve and liquidity requirements, capital adequacy requirements and capital account restrictions. This formulation essentially represents a generalized Cobb-Douglas production function, in which total factor productivity is modelled explicitly and is attributed to financial development and financial policies. It nests the AK model as a special case in which $\beta_{1}=\beta_{2}=0$. In general $\beta_{1}$ (the capital elasticity minus unity) is expected to be negative, while $\beta_{2}$ (the elasticity of employment) is expected to be positive. The degree of returns to scale is therefore given by $1+\beta_{1}+\beta_{2}$.

\section{Tests for the Order of Integration in a Series}

We first carry out unit root tests on each of the variables for the different countries $i=1, \ldots, N$ using the Augmented Dickey-Fuller (ADF) procedure to examine orders of integration of the series. The ADF regression (here including a time trend) is:

$$
\Delta x_{i t}=\alpha_{i}+\beta_{i} t+\gamma_{i} x_{i, t-1}+\sum_{j=1}^{\rho_{i}} \rho_{i j} \Delta x_{i t-j}+\varepsilon_{i j} .
$$

Lag length $(p)$ is set at a level to ensure that errors are white noise.

We then use panel unit root tests following the procedure proposed by Im, Pesaran and Shin [1996]. This method allows for heterogeneity in the panel dynamics and error variances across the $N$ groups. Im, Pesaran, and Shin [1996] propose using a group mean $\mathrm{ADF} t$-test, which is distributed as a standard normal under the unit 
root null hypothesis. Specifically, the group mean ADF $t$-test is used to test the null hypothesis that all the series in the panel have a unit root $\left(H_{0}: \gamma_{i}=0\right.$ for all $\left.i\right)$ against the stationary alternative that only a fraction $N_{1} / N$ of the series are stationary $\left(H_{1}: \gamma_{i}<0, i=1,2, \ldots, N_{1}, \gamma_{i}=0, i=N_{i}+1, N_{1}+2, \ldots, N\right)$. If the null hypothesis cannot be rejected, then it is possible to conclude that the panel data series are $I(1)$.

The group mean ADF $t$-bar statistics is given by

$$
\begin{gathered}
Z_{\bar{t}}=\sqrt{N}\left(\bar{t}_{N T}\right)-E\left(\bar{t}_{N T}\right) / \sqrt{\operatorname{Var}}\left(\bar{t}_{N T}\right), \\
\bar{t}_{N, T}=N^{-1} \sum_{i=1}^{N} \bar{t}_{i, T}\left(\gamma_{i}, \theta_{i}\right)
\end{gathered}
$$

where $N$ is the number of groups, $T$ is the number of periods, and $\bar{t}_{i, T}\left(\gamma_{i}, \theta_{i}\right)$ is the individual $t$-statistics for testing $\gamma_{i}=0$ for all $i$. The relevant mean $\left[E\left(\bar{t}_{N T}\right)\right]$ and variance $\left[\sqrt{\operatorname{Var}}\left(\bar{t}_{N T}\right)\right]$ for a selection of sample sizes and lag structures for models including intercepts and time trend are tabulated in Im, Pesaran, and Shin [1996]. Im, Pesaran, and Shin [1996] show that $Z_{\bar{t}}$ statistic converges weakly to a standard normal distribution. Hence, to test whether a series in a panel contains a unit root, we compare $Z_{\bar{t}}$ statistics to the critical values from a $N(0,1)$ distribution.

\section{Estimation Method}

Equation (1) is estimated using the Dynamic OLS/GLS (DOLS) single equation cointegration estimator [Phillips, 1991; Phillips and Loretan, 1991; Saikkonen, 1991], generalized by Stock and Watson [1993] to cases where regressors are not integrated of the same order. Thus, DOLS estimation allows variables integrated of order $d$, for $d>1$, to be combined with $\mathrm{I}(1)$ variables in the cointegrating vector. Under these more generalized conditions, Stock and Watson show that DOLS/DGLS are asymptotically efficient, having an asymptotic distribution that is a random mixture of normals and producing Wald test statistics with asymptotic chi-squared null distributions. Furthermore, Stock and Watson provide evidence from a Monte Carlo simulation showing that DOLS and DGLS perform well in finite samples relative to other asymptotically efficient estimators. In practical terms, the estimation of the average productivity equation by DOLS involves adding leads and lags of the first [second] differences of the $I(1)[I(2)]$ regressors to equation (1). Thus, all the nuisance parameters, which represent short-run dynamics, are $I(0)$ and are, by construction, uncorrelated with the error term of the equation [Stock and Watson, 1993]. This procedure corrects for the possible endogeneity of the non-stationary regressors, and gives estimates of the cointegrating vector which are asymptotically efficient. ${ }^{3}$

The equation is estimated simultaneously for all the countries in our data set by the Seemingly Unrelated Regression (SUR) method [Zellner, 1963]. Thus, we exploit any contemporaneous correlation of the error terms across equations, which would reflect productivity shocks common to all countries. All variables and nuisance parameters corresponding to the dynamic terms are allowed to vary across countries. 
The SUR system is estimated using Feasible GLS. Using the estimates from the SUR estimation, we then perform unit root tests on the cointegrating vector (excluding the nuisance parameters). The lag lengths for the ADF tests are chosen to ensure that the error terms are white noise. Finally, we construct the panel cointegration statistic and compare it to the critical values given by Pedroni [1998].

This method of exploiting the cross-section dimension of the data set while respecting the time-series properties of the data, without aggregating or pooling, allows us to address the problem of inconsistent estimates in dynamic heterogeneous panels identified by Pesaran and Smith [1995]. There are also clear advantages over the cross-section growth regressions where all long-run and dynamic parameters as well as the intercept are assumed identical across countries. Finally, the use of DOLS as opposed to other cointegration estimators is justified by recent work by Kao and Chiang [1997], which shows that it performs better than other single-equation cointegration estimators in panels of up to size $N=20$.

\section{FINANCIAL POLICIES DATA SET}

The financial policies data set used for this analysis has been uniquely constructed from information available in the Central Bank annual reports from each country from 1955 to 1996. The data we gathered comprise controls and regulations concerning the operation of domestic financial intermediaries as well as restrictions on inward and outward flows of capital. Specifically, we extracted information relating to interest rate restraints, reserve and liquidity requirements, regulations on capital adequacy, and restrictions on the flow of capital. The details on capital flow regulations were further enhanced by the IMF annual report on Exchange Controls and Capital Flows.

The choice of countries was driven by the objective of covering a broad spectrum of experiences in relation to economic development. We initially collected data on the financial policies of twenty-four countries. However, for ten of these countries the data is fragmented and/or limited and cannot, therefore, be used for time-series estimations. Consequently, these data constraints limited the number of countries that could be used for estimation purposes to fourteen, of which six could be considered developing. Specifically, the developed countries in our sample are Australia, Finland, France, Germany, New Zealand, Sweden, the United States, and the UK. The developing countries are Greece, Turkey, the Philippines, Thailand, Korea, and India.

Table 1A summarizes the main financial policies for our sample of countries. It also provides the basis for the construction of four quantitative summary measures of financial policies. Below we provide a descriptive account of these policies.

\section{Interest Rate Restraints}

Table 1A suggests that developed countries have different experiences when it comes to interest rate liberalization. The UK is the only country in our sample that did not resort to interest rate controls. United States resorted only to deposit rate controls, while Finland imposed controls on lending rates. The rest of the countries in our sample imposed both types of controls. The timing of liberalization also differs 
substantially across countries. While Germany abolished controls on lending and deposit rates in the late 1960 s, it is not until the late 1970s and mid-1980s that the rest of the countries underwent financial liberalization, which indicates that this is a relatively recent phenomenon, even in developed countries. Financial liberalization was also not homogenous across countries. In Germany and New Zealand controls on lending and deposit rates were abolished simultaneously. In Australia and Sweden, deposit rates were liberalized first followed by lending rates, while in France it was the other way around. The pace of liberalization also differs considerably across countries. While countries such as New Zealand and Australia opted for rapid financial liberalization, other countries such as France and Sweden resorted to a more gradual approach. In the developing world, the experiences across countries also differ substantially. In Turkey, Thailand and Philippines, financial liberalization occurred fast while it was much slower in Korea and Greece. It is interesting to note that in few countries (New Zealand, Turkey and India), financial liberalization did not run smoothly, and few reversed reforms.

\section{Liquidity Requirements}

The countries in the sample have different experiences regarding liquidity requirements. Finland, the United States, and New Zealand had no formal liquidity ratios throughout the sample period. At the other end of the spectrum, Germany and France, until recently, applied very high liquidity ratios. By the early 1990s, however, as Table 1A shows, most countries in our sample had abolished liquidity ratios with the exception of France, where credit institutions are required to cover their liabilities by at least an equivalent amount of liquid assets, and Australia, where banks must maintain a high quality of liquid assets and government securities equivalent to 12 percent of total liabilities. In the second group of countries, the Philippines, Korea, and Turkey did not impose any formal liquidity ratios. On the other hand, India significantly increased its liquidity ratios to as high as 38.5 percent in the 1980 s and the 1990s. Greece also resorted heavily to liquidity requirements in the $1980 \mathrm{~s}$; banks there were required to invest a certain fraction of their total deposits in short term government bonds. However, these requirements were abolished in 1993.

\section{Reserve Requirements}

All the countries in our sample have, at some stage, used reserve requirements for the conduct of monetary policy. However, it is interesting to note that in a few countries such as Sweden, New Zealand, and the UK, cash reserve requirements were completely abolished in the mid-1980s and early 1990s. In France and Australia, reserve requirements were reduced to very low levels ( 1 percent). This raises some interesting questions about the ability of a country to conduct monetary policy without reserve requirements and the impact of such developments on short-term interest rates [Sellon and Weiner, 1996]. Reserve requirements were in general higher in the group of developing countries than in the group of developed countries. Until 1995, Turkey, Greece, the Philippines, Korea, and India imposed very high reserve 
requirements although recently Greece and Korea have lowered their reserve requirements considerably. The only exception is Thailand, where reserve requirements were set at very low levels throughout the sample period.

\section{Restrictions on Capital Inflows}

Table 1A indicates that many developed countries in the early 1980s had controls on capital inflows. The only two exceptions were Germany, which lifted most controls in 1973, and United States, which in 1974 abolished the limited controls imposed in the 1960s. In the UK, capital controls were relaxed in 1979. For the remaining economies in the sample, capital account liberalization efforts did not take place until the mid-1980s and were only completed in the 1990s. For instance, in Finland capital controls were abolished only during 1991-93. In Sweden and France, capital controls were relaxed only in 1990. These examples clearly suggest that abolition of restrictions on capital inflow is a very recent phenomenon in the developed world. In the developing countries group, most restrictions on capital inflows were also relaxed in the $1990 \mathrm{~s}$, except for India where a few restrictions are still in place.

\section{Capital Adequacy Requirements}

By 1993, all countries in the sample had adopted the Bank for International Settlements (BIS) capital requirements. It is interesting to note though that it is not until the 1980s that monetary authorities in the developed world embarked on setting specific guidelines for banks' capital ratios. For instance, until 1983, the Australian monetary authorities did not have any statutory power to set specific guidelines for capital ratios. In New Zealand, the Reserve Bank's role in prudential regulation was formalized only in 1986. In the United States, the UK and France, the informal system of monitoring capital ratios was replaced by a more formal system only in the early 1980s. In Finland, capital adequacy requirements were in place, but banks were granted temporary exemption, which reduced capital ratios to very low levels. The only exceptions to this general trend are Germany and Turkey, which enforced strict rules regarding banks' capital adequacy. Throughout the sample period, the German authorities required that a bank's loans and participation not exceed 18 times its liable capital. In Turkey, capital adequacy requirements had been in operation since 1962. The only country in the sample still with no formal capital adequacy requirements is the Philippines.

\section{MEASUREMENT AND DATA SOURCES}

In this section we explain the construction of each of the variables used in the estimation of equation (1). These variables comprise the average productivity of capital, capital stock, employment, financial development, and a vector of financial policy variables. The number of policy variables included in this vector was determined through a combination of statistical criteria and economic reasoning. Statistical criteria included the prevention of multicollinearity, which suggested keeping the num- 
ber of policy variables as low as possible. Economic reasoning allowed lumping controls on deposit and lending rates with reserve requirements on different types of bank deposits. Strong positive correlations between variables suggested lumping various types of restrictions on capital flows with reserve and liquidity requirements. We were thus left with four summary measures of financial policies, with relatively low correlations between them.

The macroeconomic variables were constructed from data available from International Financial Statistics (IMF) and from the World Bank data set compiled by Nehru and Dareshwar [1993]. These data sources allow us to construct the average productivity of capital and the financial development variable (the ratio of nominal claims on the private sector to GDP). We measure the average productivity of capital by the ratio of the flow of current output to capital stock. We construct the measure using the real GDP and capital stock series available from 1963 to 1990 from the World Bank Database as compiled by Nehru et al. [1993]. Capital stock figures from 1991 to 1995 were constructed, following the perpetual inventory method assuming a depreciation rate of 4 percent and up-rating the price of capital goods in line with the GDP deflator. Investment and GDP data were obtained from International Financial Statistics [CD-ROM, 1998, 6]. Data on employment were obtained from the International Labor Statistics [various issues]. ${ }^{4}$ Financial development is measured by the ratio of nominal claims on private sector to nominal GDP. The data source for both these variables is International Financial Statistics [ibid., 6].

We construct four summary policy variables, namely interest rate restraints (IRC), reserve and liquidity requirements $(R R)$, capital adequacy requirements $(K A D)$ and restrictions on capital inflows $(C C)$. The first policy variable-interest rate restraintsis an unweighted average of lending rate and deposit rate control dummies (which take the value of 1 if a control is present, 0 otherwise). The second policy variablereserve and liquidity requirements - is a weighted average of the first two principal components of reserve requirements on demand, saving and time deposits and liquidity ratios. ${ }^{5}$ The weights chosen correspond to the relative variance of each component. For each country, the resulting index is positively correlated with the underlying variables.

The third policy variable — capital adequacy requirements-is constructed from data collected mainly from central bank reports. In years when there were no formal minimum capital adequacy standards in effect, the variable takes the value of zero. ${ }^{6}$ It is important to note that the regulatory definition of capital has changed over the years in many countries. This would have implications for capital adequacy even during periods when there have been no changes in capital adequacy requirements. ${ }^{7}$ However, the lack of relevant data did not allow us to adjust the series to changes in the regulatory definition of capital.

The fourth policy variable is an arithmetic average of the dummy for restrictions on inward portfolio investment and the dummy for inward foreign direct investment. These dummies are constructed by collecting information on these policies from various sources, mainly the IMF Annual Report on Exchange Restrictions [various issues]. 
TABLE 1

Unit Root Tests For Level of Series (1955-1996)

\begin{tabular}{lrrrrrrr}
\hline Developed Countries & LK & LL & LFD & IRC & RR & KAD & CC \\
\hline Australia & & & & & & & \\
Finland & -0.033 & -1.416 & -0.934 & -1.813 & -1.521 & -1.481 & -2.464 \\
France & 2.300 & -0.048 & -1.115 & -1.742 & -1.450 & -0.983 & -1.943 \\
Germany & -1.667 & -1.840 & -0.943 & -2.426 & -1.454 & -2.092 & -0.785 \\
New Zealand & -1.801 & -2.018 & -2.567 & -1.592 & -1.597 & -2.177 & -1.917 \\
Sweden & -0.853 & -2.660 & -0.328 & -3.803 & -2.679 & -0.936 & -1.754 \\
UK & -0.864 & -0.266 & -2.122 & -2.028 & -1.194 & -2.448 & -2.028 \\
United States & -1.476 & -2.551 & -1.644 & - & -2.093 & -1.507 & -2.294 \\
Panel Statistic & -1.205 & -2.692 & -3.713 & -2.002 & -2.131 & -1.979 & -2.053 \\
& $\mathbf{- 0 . 6 9 9}$ & $\mathbf{- 1 . 6 8 6}$ & $\mathbf{- 1 . 6 7 0}$ & $\mathbf{- 2 . 2 0 0}$ & $\mathbf{- 1 . 7 6 4}$ & $\mathbf{- 1 . 7 0 0}$ & $\mathbf{- 1 . 9 0 4}$ \\
\hline Developing Countries & & & & & & & \\
\hline Greece & $\mathbf{L K}$ & $\mathbf{L L}$ & $\mathbf{L F D}$ & $\mathbf{I R C}$ & $\mathbf{R R}$ & $\mathbf{K A D}$ & $\mathbf{C C}$ \\
Turkey & & & & & & & \\
Philippines & -1.855 & -1.902 & -0.210 & -1.322 & -0.841 & -1.908 & -0.995 \\
Thailand & 0.177 & -1.867 & -2.668 & -2.980 & -0.624 & -0.162 & -3.057 \\
Korea & -2.601 & -3.207 & -2.338 & -1.577 & -2.329 & - & -1.239 \\
India & -2.953 & -2.982 & -2.969 & 0.096 & -2.403 & - & -0.523 \\
Panel Statistic & 0.105 & -1.517 & -1.275 & -2.238 & - & - & -0.873 \\
\hline & -3.082 & -0.307 & -3.693 & -1.374 & -2.444 & - & -1.491 \\
& $\mathbf{- 1 . 7 0 1}$ & $\mathbf{- 1 . 9 6 3}$ & $\mathbf{- 2 . 1 9 2}$ & $\mathbf{- 1 . 5 6 5}$ & $\mathbf{- 1 . 7 2 8}$ & $\mathbf{- 1 . 0 3 5}$ & $-\mathbf{1 . 3 6 3}$ \\
\hline
\end{tabular}

1. $L K$ is the logarithm of the capital stock employed; $L L$ is the logarithm of the number of workers employed; $L F D$ is the logarithm of the ratio of nominal claims on private sector to nominal GDP; IRC is the index of interest rate controls; $R R$ is the index of liquidity and reserve requirements; $K A D$ is an index of capital adequacy requirements; $C C$ is an index of restrictions on capital inflows.

2. Critical values of Panel Statistic with time trend for the developed countries group: 1 percent $=-2.90$, 5 percent $=-2.68 ; 10$ percent $=-2.57$. [Im, Pesaran and Smith, 1996].

3. Critical values of Panel Statistic with time trend for the developing countries group: 1 percent $=-2.93$, 5 percent $=-2.69 ; 10$ percent $=-2.57$. [Im, Pesaran and Smith, 1996].

\section{EMPIRICAL RESULTS}

We report unit root tests for the various variables for the two groups of countries: developed and developing ones. The unit root tests on the level of the series clearly show that the null of a unit root in the level of the series cannot be rejected for any of the fourteen countries (Table 1), while the same hypothesis is strongly rejected for the first-differenced level series at the 1 percent level of significance, except for capital stock where we cannot reject the null of a unit root in the first difference of the capital stock series (Table 2). The panel statistic clearly confirms that all variables are integrated of order one, except for the capital stock series, which was found to be $I(2)$.

The next step in our empirical investigation involves applying the DOLS estimator to estimate the average productivity equation. The equation is estimated separately for each country, and the residuals of the regression are subjected to a test to ascertain whether the SUR technique, which assumes dependence among the equations, should also be utilized. We therefore formally test the null hypothesis that the 
TABLE 2

Unit Root Tests For Differences of Series

\begin{tabular}{|c|c|c|c|c|c|c|c|c|}
\hline Developed Countries & $\Delta \mathbf{L K}$ & $\Delta^{2} \mathbf{L K}$ & $\Delta \mathbf{L L}$ & $\Delta$ LFD & $\Delta \mathrm{IRC}$ & $\Delta \mathbf{R R}$ & $\Delta \mathbf{K A D}$ & $\Delta \mathbf{C C}$ \\
\hline Australia & -0.894 & -5.221 & -5.833 & -4.420 & -6.573 & -6.503 & -6.476 & -6.349 \\
\hline Finland & -1.559 & -3.999 & -3.340 & -2.877 & -6.403 & -4.118 & -6.340 & -6.695 \\
\hline France & 0.559 & -4.528 & -6.059 & -5.334 & -6.538 & -6.689 & -6.553 & -5.791 \\
\hline Germany & -1.019 & -6.063 & -5.673 & -6.057 & -6.403 & -6.664 & -6.527 & -6.043 \\
\hline New Zealand & -2.354 & -4.782 & -4.788 & -4.343 & -5.712 & -8.614 & -6.437 & -5.811 \\
\hline Sweden & 0.208 & -4.230 & -4.453 & -5.543 & -6.573 & -6.573 & -8.473 & -6.960 \\
\hline UK & -0.645 & -4.687 & -4.656 & -4.257 & - & -6.472 & -6.547 & -6.759 \\
\hline United States & -2.677 & -5.875 & -5.603 & -6.108 & -6.403 & -7.040 & -6.503 & -6.245 \\
\hline Panel Statistic & -1.047 & -4.923 & -5.050 & -4.867 & -6.372 & -6.584 & -6.732 & -6.331 \\
\hline Developing Countries & $\Delta \mathbf{L K}$ & $\Delta^{2} \mathbf{L K}$ & $\Delta \mathbf{L L}$ & $\Delta \mathbf{L F D}$ & $\Delta$ IRC & $\Delta \mathbf{R R}$ & $\Delta \mathbf{K A D}$ & $\Delta \mathbf{C C}$ \\
\hline Greece & -0.897 & -5.131 & -5.846 & -4.065 & -5.789 & -4.078 & -5.855 & -5.534 \\
\hline Turkey & -0.105 & -5.337 & -5.975 & -4.673 & -5.595 & -5.365 & -5.142 & -7.236 \\
\hline Phillipines & -1.276 & -3.681 & -5.551 & -3.396 & -4.140 & -4.255 & - & -5.814 \\
\hline Thailand & -1.381 & -4.442 & -6.161 & -3.505 & -5.000 & -7.869 & - & -4.827 \\
\hline Korea & -2.350 & -3.867 & -4.590 & -3.100 & -5.361 & - & - & -6.198 \\
\hline India & -1.792 & -4.714 & -3.694 & -9.217 & -5.082 & -5.847 & - & -5.855 \\
\hline Panel Statistic & -1.300 & -4.528 & -5.302 & -4.659 & -5.161 & -5.482 & -5.498 & -5.910 \\
\hline
\end{tabular}

See notes from Table 1.

covariance matrix is diagonal. If we accept the null hypothesis, OLS is efficient and there are no efficiency gains in using SUR. We use the Lagrange multiplier test suggested by Breusch and Pagan [1980], which is composed of the sum of the squared correlation coefficients multiplied by the number of observations. This statistic is asymptotically distributed as chi squared with $M(M-1) / 2$ degrees of freedom where $M$ is the number of countries included in the panel. According to this statistic, the hypothesis that the covariance matrix is diagonal can be rejected at the 1 percent level. ${ }^{8}$ This indicates that significant efficiency gains can be achieved from exploiting the contemporaneous correlation across countries using SUR.

The results of the DOLS regression using the SUR technique are presented in Tables 3 and 4. According to the ADF statistic, individual cointegrating vectors show a high degree of cointegration with the exception of Finland in the developed economies group and Turkey in the developing economies group. When considering the panel as a whole, the evidence of cointegration is very strong in the developed economies group, but weaker in the developing economies group for which we cannot reject the null of a unit root.

Tables 3 and 4 also report the estimated coefficients in each cointegrating vector. The estimated coefficients of the logarithm of the capital variable are reasonable and are precisely estimated, as indicated by the low standard errors. The implied capital stock elasticities take plausible values, ranging from 0.47 for the UK to 0.91 for Finland. With perhaps the exception of India, the estimated employment elasticities are also sensible, even though they are imprecisely estimated in the case of Turkey and 
TABLE 3

Cointegration Analysis for Developed Countries (1955-1996)

\begin{tabular}{|c|c|c|c|c|c|c|c|c|c|}
\hline Country & Cons & $\boldsymbol{L K}$ & $L L$ & $L F D$ & $I R C$ & $\boldsymbol{R R}$ & $K A D$ & $C C$ & ADF \\
\hline \multirow[t]{2}{*}{ Australia } & $4.716^{\mathrm{a}}$ & $-0.256^{\mathrm{a}}$ & $0.126^{\mathrm{a}}$ & $0.038^{a}$ & $0.032^{\mathrm{a}}$ & $0.018^{\mathrm{a}}$ & $0.006^{\mathrm{a}}$ & $-0.068^{a}$ & -5.110 \\
\hline & 0.422 & 0.024 & 0.034 & 0.021 & 0.010 & 0.005 & 0.002 & 0.013 & \\
\hline \multirow[t]{2}{*}{ Finland } & 0.769 & $-0.087^{a}$ & 0.031 & $0.105^{b}$ & 0.005 & $0.008^{\mathrm{a}}$ & $0.006^{\mathrm{b}}$ & $0.100^{\mathrm{a}}$ & -2.761 \\
\hline & 0.578 & 0.028 & 0.103 & 0.059 & 0.015 & 0.003 & 0.003 & 0.022 & \\
\hline \multirow[t]{2}{*}{ France } & $11.796^{\mathrm{a}}$ & $-0.451^{\mathrm{a}}$ & $0.068^{\mathrm{a}}$ & 0.002 & $-0.169^{a}$ & $0.008^{\mathrm{a}}$ & $0.026^{\mathrm{a}}$ & $0.105^{\mathrm{a}}$ & -3.878 \\
\hline & 0.495 & 0.017 & 0.007 & 0.012 & 0.017 & 0.001 & 0.003 & 0.014 & \\
\hline \multirow[t]{2}{*}{ Germany } & $10.018^{a}$ & $-0.416^{\mathrm{a}}$ & $0.118^{a}$ & $0.325^{\mathrm{a}}$ & $0.062^{\mathrm{a}}$ & $0.036^{\mathrm{a}}$ & $-0.011^{\mathrm{a}}$ & $-0.097^{\mathrm{a}}$ & -3.477 \\
\hline & 1.093 & 0.041 & 0.023 & 0.048 & 0.008 & 0.002 & 0.001 & 0.022 & \\
\hline \multirow[t]{2}{*}{ New Zealand } & $5.219^{\mathrm{a}}$ & $-0.431^{\mathrm{a}}$ & $0.648^{a}$ & 0.028 & $0.030^{\mathrm{a}}$ & $-0.021^{\mathrm{a}}$ & $-0.006^{\mathrm{a}}$ & $0.339^{\mathrm{a}}$ & -4.034 \\
\hline & 0.712 & 0.062 & 0.128 & 0.024 & 0.007 & 0.001 & 0.002 & 0.024 & \\
\hline \multirow[t]{2}{*}{ Sweden } & $8.058^{a}$ & $-0.488^{a}$ & $0.581^{\mathrm{a}}$ & $0.081^{\mathrm{a}}$ & -0.016 & $0.041^{\mathrm{a}}$ & $0.005^{\mathrm{a}}$ & $-0.088^{a}$ & -3.979 \\
\hline & 0.624 & 0.040 & 0.085 & 0.025 & 0.009 & 0.016 & 0.002 & 0.021 & \\
\hline \multirow[t]{2}{*}{ UK } & $11.672^{\mathrm{a}}$ & $-0.533^{a}$ & $0.214^{\mathrm{a}}$ & $0.086^{\mathrm{a}}$ & - & -0.003 & -0.014 & $-0.058^{a}$ & -5.721 \\
\hline & $1.113^{\mathrm{a}}$ & 0.022 & 0.103 & 0.009 & & 0.003 & 0.014 & 0.028 & \\
\hline \multirow[t]{2}{*}{ United States } & $7.464^{\mathrm{a}}$ & $-0.417^{a}$ & $0.347^{\mathrm{a}}$ & $0.413^{\mathrm{a}}$ & $0.033^{\mathrm{a}}$ & 0.003 & -0.002 & -0.032 & -4.350 \\
\hline & 3.129 & 0.163 & 0.176 & 0.105 & 0.013 & 0.005 & 0.002 & 0.051 & \\
\hline \multicolumn{2}{|c|}{ Panel Statistic } & & & & & & & & -4.163 \\
\hline
\end{tabular}

See note 1 from Table 1.

2. The method of estimation is DOLS [Stock and Watson, 1993]. Given the small number of observations, to avoid over-parameterization we only retain significant lags and leads [Inder, 1995].

3. $\mathrm{ADF}$ is the augmented Dickey Fuller test on the residuals of the cointegrating vector excluding the nuisance parameters.

4. Critical values for the panel cointegration statistic without time trend is -3.795 [Pedroni,1998].

a. Significant at the 1 percent level;

b. Significant at the 5 percent level.

TABLE 4

Cointegration Analysis for Developing Countries (1955-1996)

\begin{tabular}{|c|c|c|c|c|c|c|c|c|c|}
\hline Country & Cons & $L K$ & $L L$ & $L F D$ & IRC & $\boldsymbol{R R}$ & $K A D$ & $\boldsymbol{C C}$ & ADF \\
\hline \multirow[t]{2}{*}{ Greece } & 2.053 & $-0.321^{\mathrm{a}}$ & $0.449^{b}$ & 0.073 & $-0.065^{a}$ & -0.005 & $-0.098^{a}$ & 0.007 & -3.802 \\
\hline & 4.139 & 0.019 & 0.276 & 0.033 & 0.024 & 0.005 & 0.021 & 0.030 & \\
\hline \multirow[t]{2}{*}{ Turkey } & $6.145^{\mathrm{a}}$ & -0.269 & 0.167 & $0.200^{\mathrm{a}}$ & $0.100^{\mathrm{a}}$ & 0.010 & $0.773^{\mathrm{a}}$ & $-0.102^{\mathrm{a}}$ & -2.002 \\
\hline & 0.977 & 0.047 & 0.138 & 0.060 & 0.024 & 0.006 & 0.064 & 0.051 & \\
\hline \multirow[t]{2}{*}{ Philippines } & $4.833^{\mathrm{a}}$ & $-0.243^{\mathrm{a}}$ & 0.107 & $0.085^{\mathrm{a}}$ & $0.181^{\mathrm{a}}$ & 0.002 & - & $0.088^{a}$ & -3.460 \\
\hline & 0.984 & 0.061 & 0.104 & 0.022 & 0.032 & 0.008 & & 0.048 & \\
\hline \multirow[t]{2}{*}{ Thailand } & $9.332^{\mathrm{a}}$ & $-0.504^{\mathrm{a}}$ & $0.445^{\mathrm{a}}$ & $0.160^{\mathrm{a}}$ & $-0.233^{\mathrm{a}}$ & -0.015 & - & $0.795^{\mathrm{a}}$ & -3.371 \\
\hline & 1.577 & 0.064 & 0.108 & 0.068 & 0.053 & -0.015 & & 0.304 & \\
\hline \multirow[t]{2}{*}{ Korea } & $6.145^{\mathrm{a}}$ & $-0.514^{\mathrm{a}}$ & $0.565^{\mathrm{b}}$ & $0.084^{\mathrm{a}}$ & 0.007 & - & - & $-0.176^{\mathrm{a}}$ & -3.442 \\
\hline & 0.755 & 0.106 & 0.342 & 0.040 & 0.164 & & & 0.055 & \\
\hline \multirow[t]{2}{*}{ India } & $2.001^{\mathrm{a}}$ & $-0.363^{a}$ & $0.801^{\mathrm{a}}$ & 0.002 & $-0.139^{a}$ & -0.013 & - & $-0.126^{a}$ & -3.679 \\
\hline & 0.827 & 0.067 & 0.179 & 0.011 & 0.024 & 0.010 & & 0.045 & \\
\hline \multicolumn{3}{|c|}{ Panel Statistic } & & & & & & & -3.292 \\
\hline
\end{tabular}

See notes 1,2 , and 3 from Table 3 .

4. Critical values for Panel Cointegration statistic without time trend is -3.531 [Pedroni,1998].

a. Significant at the 1 percent level.

b. Significant at the 5 percent level. 
the Philippines. These elasticities range from 0.03 for Finland to 0.80 for India. The weaknesses in some of the developing country estimates probably reflect the poor quality of the employment data. Nonetheless, partly because the implied capital stock elasticities are plausible, the implied degree of returns to scale takes reasonable values, ranging from 0.62 for France to 1.44 for India. Most of the developed countries exhibit returns to scale that are below unity. For example, the implied degree of returns to scale for the UK is 0.68 and 0.93 for the United States. On the other hand, New Zealand and Sweden's are 1.22 and 1.09 respectively. The developing economies, except fo India exhibit implied returns to scale in the range of $0.86-1.12$, which appear reasonable.

Tables 3 and 4 also reveal that in most countries the financial development indicator enters significantly with the expected positive sign. The exceptions are France and New Zealand in the developed group and Greece and India in the developing group, where although the financial development indicator has the expected sign it is not significant at the conventional levels.

As to financial policies, the results are generally mixed. Starting with interest rate restraints, these are insignificant in the case of Finland and Sweden. Importantly, in Australia, Germany, New Zealand and the United States, interest rate restraints enter with a positive sign and are statistically significant. On the other hand, in France they appear to have a negative impact on the average productivity of capital. It is important to note here that interest rate restraints in France were more severe than in other developed countries, which may be a factor that helps to explain why they had a negative impact. The effects of interest rate restraints are also mixed in the developing economies group. Specifically, we find that interest rate restraints have a negative impact on average productivity of capital in Greece, India, and Thailand, while they have a positive impact in Turkey and Philippines.

The impact of reserve and liquidity requirements also varies across countries. Reserve requirements enter significantly with a positive sign in almost all countries except for New Zealand where the impact is negative, and in the UK and the United States where reserve requirements were found to have no significant impact on the average productivity of capital. Interestingly, reserve requirements are insignificant in all countries of the developing economies group. The impact of capital adequacy requirements is also not homogenous across countries. In many countries such as Australia, Finland, France, Sweden, and Turkey, capital adequacy requirements seem to have contributed positively to the average productivity of capital. On the other hand, in countries like New Zealand, Greece, and Germany capital adequacy adversely affected the productivity of capital. In the case of Germany, this result can be partly explained by the excessive requirements that were imposed in 1974 on banks as a reaction to the crash of the Herstat Bank. Interestingly, in the UK and the United States, capital adequacy ratios are not significant. The evidence of the impact of capital inflow restrictions on average productivity is again mixed. In the UK, Sweden, Germany, and Australia, the dummy for capital inflows enters significantly with a negative sign. On the other hand, in Finland, New Zealand, and France, this indicator enters positively. In the developing group, the evidence is also mixed. The indicator enters negatively in Korea, India, and Turkey, but positively in the case of 
TABLE 5

Restriction Tests for Equality of Coefficients Across Equations

\begin{tabular}{lrr}
\hline & Developed & Developing \\
\hline$L K$ & & \\
& 191.137 & 14.010 \\
$L L$ & 0.000 & 0.000 \\
& 69.252 & 15.308 \\
$L F D$ & 0.000 & 0.009 \\
& 71.049 & 31.785 \\
$I R C$ & 0.000 & 0.000 \\
& 164.591 & 88.058 \\
$R R$ & 0.000 & 0.000 \\
& 371.087 & 5.910 \\
$K A D$ & 0.000 & 0.206 \\
& 140.165 & 162.577 \\
$C C$ & 0.000 & 0.000 \\
& 337.806 & 30.652 \\
& 0.000 & 0.000 \\
\hline
\end{tabular}

See note 1 from Table 2 .

1. The null hypothesis: coefficients are equal across equations. We use the Wald statistic to test the null hypothesis.

2. p-values of the Wald statistic given below coefficients.

Philippines and Thailand. In the latter country, this result is not surprising since most of the restrictions were imposed on short-term flows whereas FDI flows were liberalized from the early 1970s.

Taken together these results suggest quite clearly that the impact of financial policies varies considerably across countries. This is confirmed by testing for the equality of coefficients across equations using the Wald statistic. As Table 5 clearly suggests, in the case of developed countries, we reject the null hypothesis that coefficients are equal across equations. In the developing group, we obtain similar results, except for reserve requirements where the null hypothesis that coefficients are equal across equations cannot be rejected at conventional levels. The differences in the effects of financial policies probably reflect institutional differences across countries, including the strength of banking supervision and regulation, the structure of the banking system and its relationship to industry and government. These institutions are likely to influence the implementation of financial policies, which may be a decisive factor in policy effectiveness. In many developing countries, for example, financial restraints may be imposed but not enforced-or enforced selectively-in the sense that any penalties imposed on institutions that do not adhere to them are ineffective. In developed economies, there are important differences between bank-based and capital-market-based financial systems, which may well account for why certain policies work differently [Arestis, Demetriades and Luintel, 2001].

Finally, it is important to note that our findings fail to provide adequate support for the financial liberalization thesis. Specifically, interest rate restraints and reserve requirements, which tend to be the focus of financial liberalization programs, 
are found to positively impact the productivity of capital in many countries. Furthermore, restrictions on capital inflows are found to have positive effects in five countries and negative effects in seven. These findings provide considerable empirical support to the argument that some form of financial restraints may indeed enhance economic efficiency. Stiglitz is, thus, justified when he argues,

\begin{abstract}
...there are a host of regulations, including restrictions on interest rates or lending to certain sectors (such as speculative real estate), that may enhance the stability of the financial system and thereby increase the efficiency of the economy. Although there may be a trade off between short-run efficiency and this stability, the costs of instability are so great that long run gains to the economy more than offset any short term losses... [1998, 33].
\end{abstract}

\title{
SUMMARY AND CONCLUDING REMARKS
}

This paper provides a novel assessment of the effects of several types of financial policies on the average productivity of capital in fourteen countries. Specifically, it uses a new data set on financial restraints, capital adequacy requirements and restrictions on capital flows in these countries, for a period of forty years, the collection of which represented a major research effort. It utilizes modern panel time-series methods to examine the effects of these policies on the productivity of capital, controlling for financial development, employment and capital. Our empirical findings suggest that the effects of these policies vary considerably across countries, probably reflecting institutional differences. They also demonstrate that the main predictions of the financial liberalization literature do not receive adequate empirical support, a result that may reflect the prevalence of financial market imperfections. In contrast, our findings provide significant support to the thesis, currently gaining increasing support among international policymakers, that some form of financial restraints may indeed have positive effects on economic efficiency.

Several fruitful avenues for further research emerge from our findings. One plausible conjecture is that financial restraints positively affect productivity where institutional quality, such as prudential regulation and supervision, is weak. To test this conjecture one would require data on the quality of the regulatory regime, a challenging but worthwhile endeavor. Other institutional quality indicators, such as the quality of legal rules and law enforcement, have been used successfully in relation to the development of capital markets [La Porta, Lopez-De-Silanas, and Vishny, 1997]. There are further under-researched theoretical aspects still to be explored with respect to the relationship investigated in this study, the most promising of which relates to the interaction between prudential and monetary control. Consequently, further work on these, and related issues, is likely to produce useful insights into the effectiveness of financial liberalization. This in its turn would be invaluable to the debate on financial globalization. 


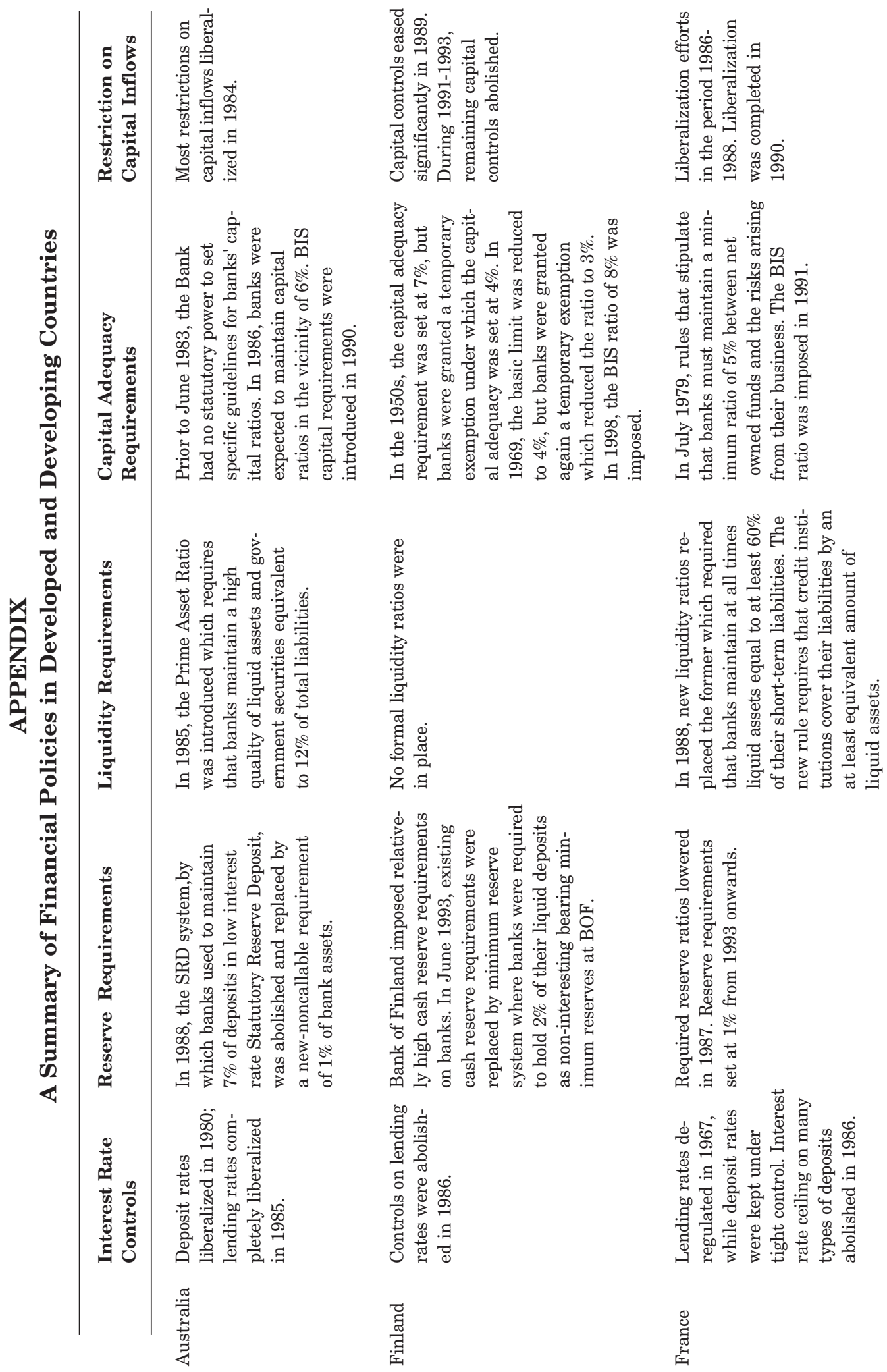




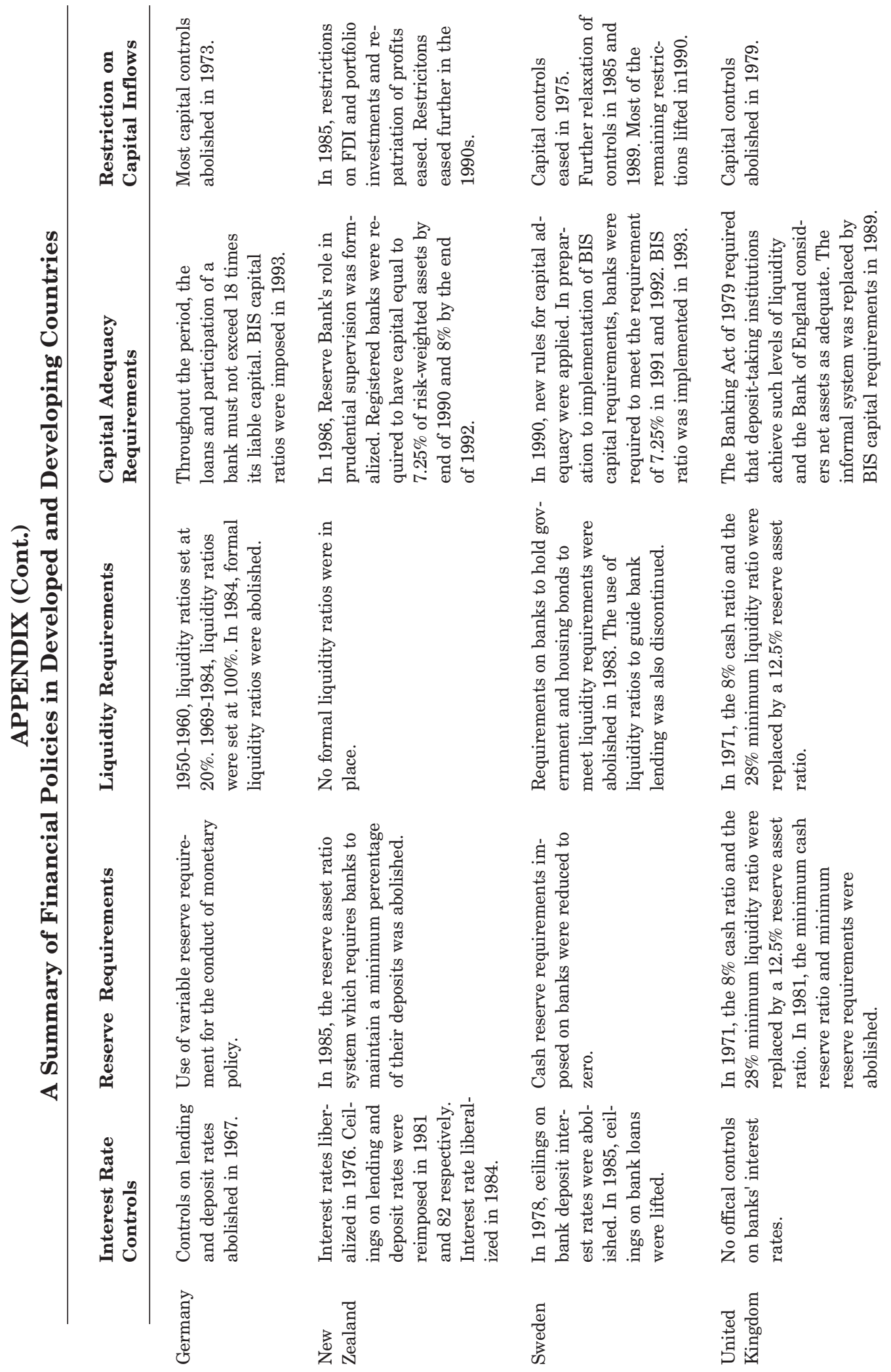




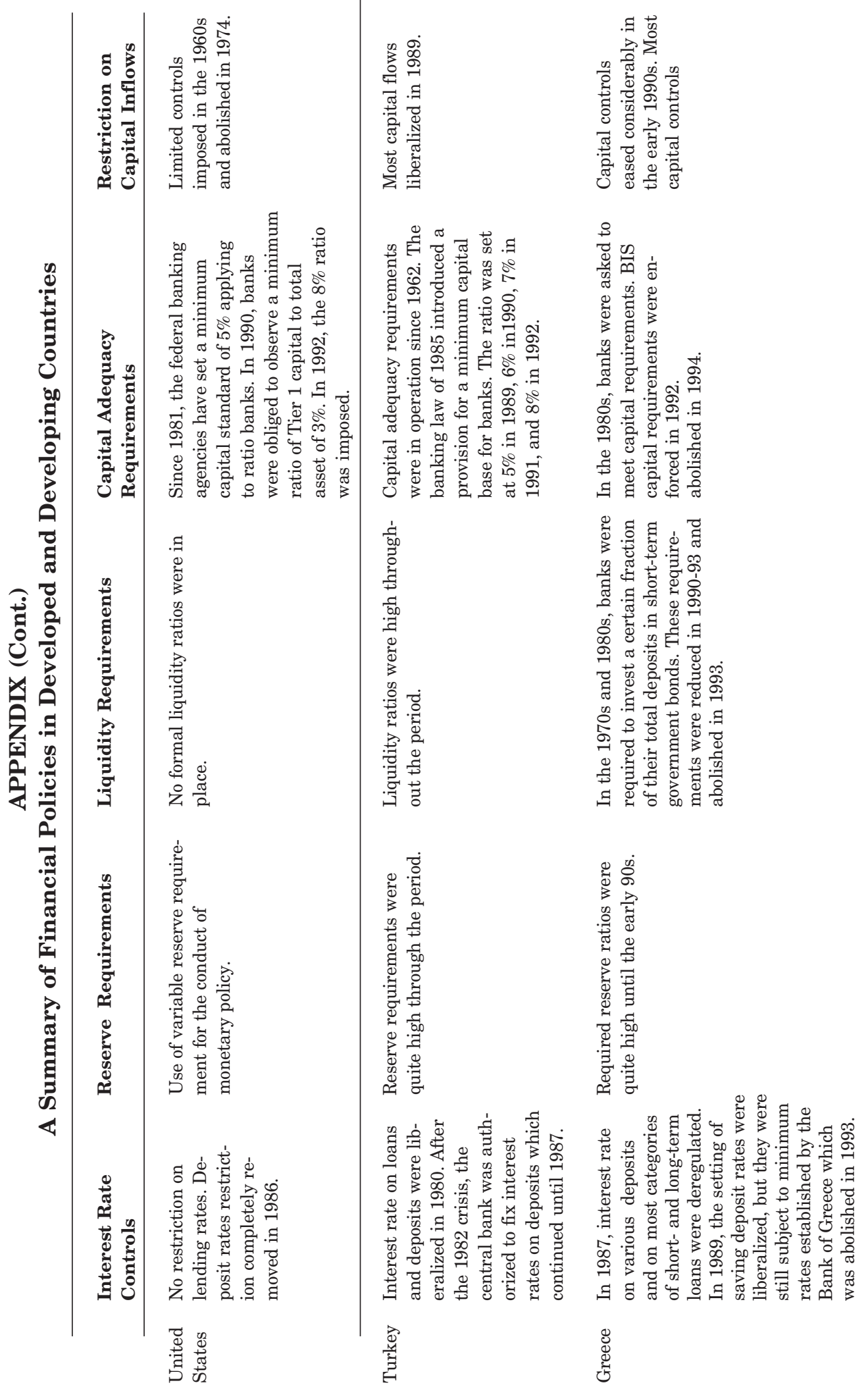




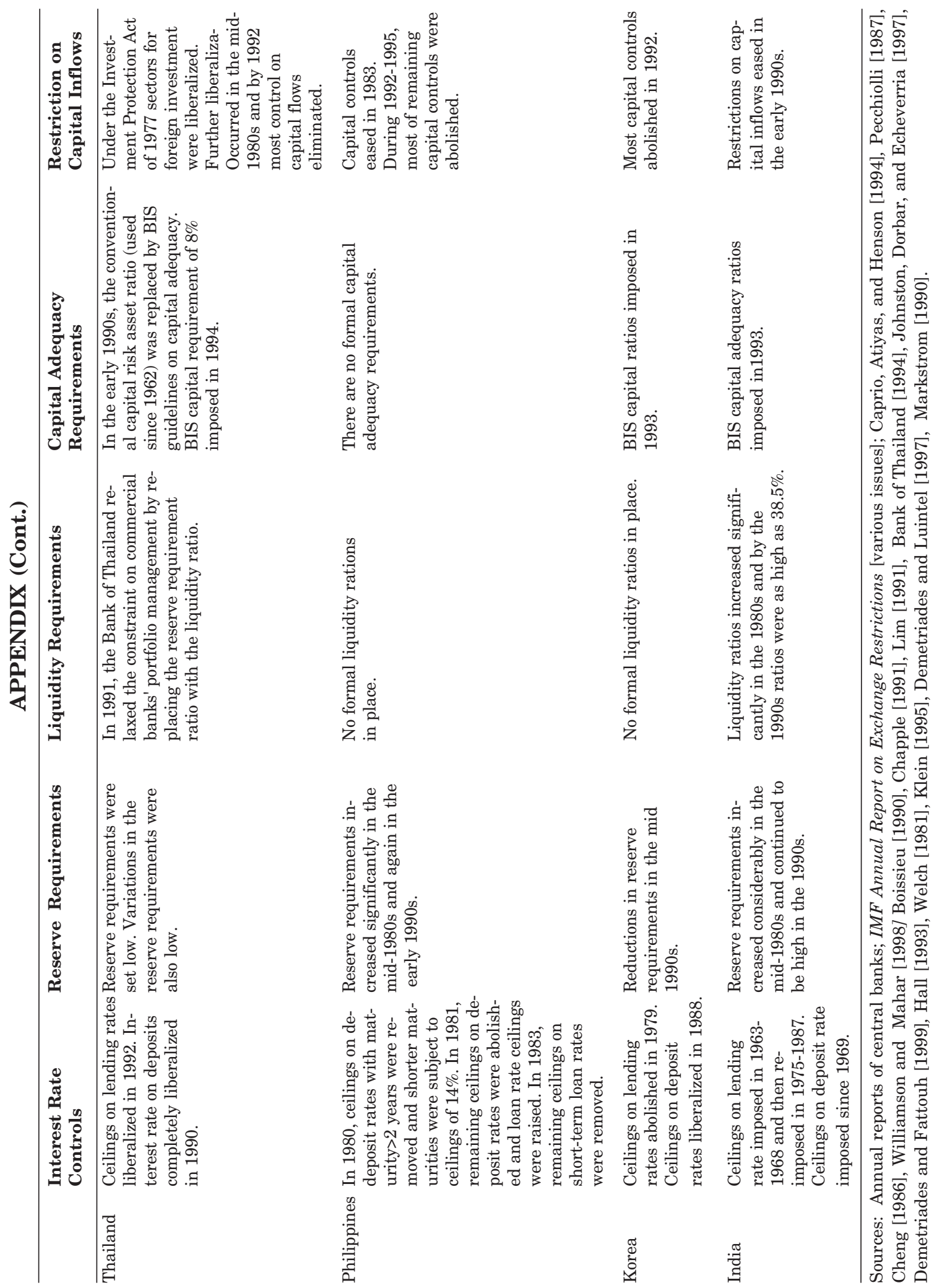




\section{NOTES}

We acknowledge financial support from the ESRC (Grant R000236463). We would like to thank David Mayes for providing us with vital links to the central banks of Finland, Sweden, Canada, and Austria. We would also like to thank Jean-Bernard Chatelain for providing us with information from the Bank of France. We are also thankful to Clare Kelly for collecting some of the data from central bank reports.

1. The precise estimates of these effects vary considerably depending on methods and data used.

2. See, for example, Demetriades, Devereux and Luintel [1998] for a relevant application in East Asia.

3. We thank Pentti Saikkonen for clarifying this point.

4. Due to data unavailability in few countries (Thailand, Sweden, India, Turkey), the labor series was extrapolated using the number of workers from the Penn World Table Data set adjusted for by the ratio of number of workers obtained from ILO to the number of workers obtained from Penn World Table Data set.

5. An exception is France where liquidity ratios were found highly correlated with capital adequacy requirements rather than reserve requirements.

6. Even when there were no formal capital adequacy requirements, in most of these countries there were some regulations aimed at assessing the riskiness of an institution's loans and other assets.

7. We are grateful to Fred Daniel of the Bank of Canada for this remark.

8. The test statistic is 100.66 for the group of developed countries. The critical value for 1 percent level of significance is 48.28 . The test statistic is 71.56 for the group of developing countries. The critical value for 1 percent level of significance is 30.58 .

\section{REFERENCES}

Akerlof, G. and Romer, P. Looting: The Economics Underworld of Bankruptcy for Profit. Brooking Papers on Economic Activity, 1993.

Arestis, P., and Demetriades, P. O. Financial Development and Economic Growth: Assessing The Evidence. The Economic Journal, May 1997, 783-99.

Arestis, P., Demetriades, P. O. and Fattouh, B. A. Financial Liberalisation and the Globalisation of Financial Services: Two Lessons from the East Asian Experience, in Regionalism and Globalisation: Theory and Practice, edited by S. Lahiri. London: Routledge, 2001.

Arestis, P., Demetriades, P., Fattouh, B. and Mouratidis, K. The Impact of Financial Liberalization Policies on Financial Development: Evidence from Developing Economies. International Journal of Economics and Finance, April 2002.

Arestis, P., Demetriades, P. O. and Luintel, K. Financial Development and Economic Growth: the Role of Stock Markets. Journal of Money, Credit and Banking, February 2001, 16-41.

Aschauer, D. A. Is Public Expenditure Productive? Journal of Monetary Economics, 1989, 177-200.

Bank of Thailand. Thailand's Financial System: Structure and Liberalisation. Bangkok: The Thailand Development Research Institute, 1994.

Berger, A. N., Herring, R. J., and Szego G. P. The Role of Capital in Financial Institutions. Journal of Banking and Finance, May 1995, 393-430.

Boissieu, C. de, ed. Banking in France. London: Routledge, 1990.

Breusch, T. and Pagan, A. The Lagrance Multiplier Test and Its Applications to Model Specification in Econometrics. Review of Economic Studies, January 1980, 239-54.

Blum, J. and Hellwig, M. The Macroeconomic Implications of Capital Adequacy Requirements for Banks. European Economic Review, April 1995, 739-49.

Calomiris, C. W. and Himmelberg, C. P. Directed Credit Programmes for Agriculture and Industry: Arguments from Theory and Fact. Proceedings of the World Bank Annual Conference on Development Economics 1993, 1994, 113-154.

Caprio, G. Banking on Financial Reform? A Case of Sensitive Dependence on Initial Conditions, in $F i$ nancial reform: Theory and Experience, edited by G.Caprio, I. Atiyas, and J. Hanson. New York: Cambridge University Press, 1994.

Caprio, G. and Summers, L. Financial Liberalisation: Beyond Laissez-Faire. World Bank Policy Research Working Papers, 1994. 
Caprio, G., Atiyas, I., and Hanson, J., eds. Fianancial Reform: Theory and Experience. New York: Cambridge University Press, 1994.

Chapple, S. Financial Liberaiszation in new Zealand, 1984-90. Geneva: United Nations Conference on Trade and Development, 1991.

Cheng, H.-S., ed. Financial Policy and Reform in Pacific Basin Countries. Lexington, MA: Lexington Books, 1990..

Demetriades, P. O., Devereux, M. P., and Luintel, K. B. Productivity and Financial Sector Policies: Evidence from South East Asia. Journal of Economic Behavior and Organization, March 1998, 6182.

Demetriades, P. O. and Fattouh, B. A. Unproductive Credit and the South Korean Crisis. Paper presented at the Royal Economic Society Conference, Nottingham, April 1999.

Demetriades, P. O. and Hussein, K. Financial Development and Economic Growth: Cointegration and Causality Tests for 16 Countries. Journal of Development Economics, 1996, 387-411.

Demetriades, P. O. and Luintel, K. B. Financial Development, Economic Growth and Banking Sector Controls: Evidence From India. The Economic Journal, December 1996, 359-74. . The Direct Costs of Financial Repression: Evidence From India. The Review of Economics and Statistics, May 1997, 359-74.

. Financial Restraints in the South Korean Miracle. Journal of Development Economics, April 2001, 459-79.

Demetriades, P. O. and Mamuneas, T. P. Intertemporal Output and Employment Effects of Public Infrastructure Capital: Evidence from 12 OECD Economies. Economic Journal, June 2000, 687-712.

Demirgüç-Kunt, A. and Detragiache, E. Financial Liberalisation and Financial Fragility. International Monetary Fund, Working Paper, 98/83, 1998.

Dewatripont, M. and Tirole, J. The Prudential Regulation of Banks. Cambridge, MA: The MIT Press, 1993.

Fry, M. J. Money, Interest and Banking in Economic Development, 2nd edition. London: Johns Hopkins University Press, 1995.

. In Favor of Financial Liberalisation. The Economic Journal, May 1997, 754-70.

. Pitfalls and Potential of Financial Liberalisation. Ekonomia, Summer 1998, 1-28.

Gelb, A. Financial Policies and Growth. Policy Research Working Paper No. 2, Washington D.C.: World Bank, 1989.

Gennotte, G. and Pyle, D. Capital Controls and Bank Risk. Journal of Banking and Finance, 1991, 805824.

Hall, M. Banking Regulation and Supervision: A Comparative Study of the UK, USA, and Japan. Aldershot: Edward Elgar, 1993.

Hancock, D., Laing, A. J., and Wilcox, J. Bank Capital Shocks: Dynamic Effects on Securities, Loans, and Capital. Journal of Banking and Finance, 1995, 661-57

Hellman, T., Murdock, K., and Stiglitz, J. E. Financial Restraint: Toward a New Paradigm, in The Role of government in East Asian Economic Development: Comparative Institutional Analysis, edited by M. Aoki, M. Okuno-Fujiwara and Kim. Oxford: Oxford University Press, 1996a.

- Deposit Mobilisation Through Financial Restraint, in Financial Development and Economic Growth, edited by N. Hermes and R. Lensink. London: Routledge, 1996b.

- Liberalisation, Moral Hazard in Banking, and Prudential Regulation: Are Capital Requirements Enough? American Economic Review, March 2000, 147-65.

Im, K. S., Pesaran, M. H., and Shin, Y. Testing for Unit Roots in Heterogenous Panel. Mimeo: University of Cambridge, 1996.

IMF Annual Report on Exchange Rate Restrictions. Washington, DC: International Monetary Fund, various years.

Inder, B. Finite Sample Arguments for Appropriate Estimation of Cointegrating Vectors. Mimeo. Monash University. Presented at teh 7th World Congress of Econometric Society, Tokyo, 1995.

International Financial Statistics. CD-ROM, Washington, DC: International Monetary Fund, $1998,6$.

International Labor Statistics. Geneva, Switzerland: International Labour Organization, various years.

Johnston, B., Dorbar, S., and Echeverria, C. Sequencing Capital Account Liberalisation: Lessons from the Experiences in Chile, Indonesia, Korea, and Thailand. IMF Working Paper 97/157, 1997. 
Kao, C. and Chiang, M. On the Estimation and Inference of a Cointegrated Regression in Panel Data. Mimeo: Syracuse University, 1997.

Keeley, M. C., and Furlong, F. T. A Reexamination of Mean-Variance Analysis of Bank Capital Regulation. Journal of Banking and Finance, March 1990, 69-84.

Kim, D., and Santomero, A. M. Risk in Banking and Capital Regulation. The Journal of Finance, December 1988, 1219-33.

Klein, D. The Banking Systems of the EU Member States. Cambridge: Woodhead Publishing, 1995.

La Porta, R., Lopez-De-Silanes, F. and Vishny, R. W. Legal Determinants of External Finance. Journal of Finance, July 1997, 1131-50.

Lim, J. Y. The Philippine Financial Sector in the 1980s. United Nations Conference on Trade and Development discussion paper no. 37. Geneiva: United Nations, 1991.

Lynde, C. and Richmond, J. Public Capital and Long-Run Costs in UK Manufacturing. The Economic Journal, July 1993, 880-93.

Markstrom, G. New Rules for Capital Adequacy in Swedish Financial Institutions. Skandinaviska Enskilda Banken Quartelry Review, 1990, 99-104.

McKinnon, R. I. Money and Capital in Economic Development. Washington D.C.: Brookings Institution, 1973.

McKinnon, R. and Pill, H. Credible Economic Liberalisation and Overborrowing. American Economic Review, May 1997, 189-93.

Nadiri, M. I. and Mamuneas, T. P. The Effects of Public Infrastructure and R\&D Capital on the Cost Structure and Performance of U.S. Manufacturing Industries. The Review of Economics and Statistics, February 1994, 22-37.

Nehru, V. and Dareshwar, A. A New Database on Physical Capital Stock: Sources, Methodology and Results. Revista de Analisis Economico, 1993, 37-59.

Pagano, M. Financial Markets and Growth: An Overview. European Economic Review, April 1993, 61322.

Pecchioli, R. M. Prudential Supervision in Banking. Paris: Organization for Economic Cooperation and Development, 1987.

Pedroni, P. Critical Values for Cointegration Test in Heterogenous Panels with Multiple Regressors. Oxford Bulletin of Economics and Statistics, 1998.

Peek, J. and Rosengren, E. Bank Regulation and the Credit Crunch. Journal of Banking and Finance, June 1995, 679-92.

Pesaran, M. H. and Smith, R. Estimating Long-run Relationships from Dynamic Heterogeneous Panels. Journal of Econometrics, July 1995, 79-113.

Phillips, P. C. B. Optimal Inference in Cointegrated Systems. Econometrica, March 1991, 283-306.

Phillips, P. C. B. and Loretan, M. Estimating Long-Run Economic Equilibria. The Review of Economic Studies, May 1991, 407-436.

Rossi, M. Financial Fragility and Economic Performance in Developing Economies-Do Capital Controls, Prudential Regulation and Supervision Matter? IMF Working Paper, WP/99/66, Washington: International Monetary Fund, 1999.

Saikkonen, P. Asymptotically Efficient Estimation of Cointegrating Regression. Econometric Theory, March 1991, 1-21.

Schiantarelli, F., Atiyas, I., Caprio, G., Harris, J. and Weiss, A. Credit Where It Is Due? A Review of the Macro and Micro Evidence on the Real Effects of Financial Reform, in Financial Reform: Theory and Experience, edited by G. Caprio, I. Atiyas and J. Hanson. New York: Cambridge University Press, 1994.

Sellon, G. H. and Wiener, S. E. Monetary Policy Without Reserve Requirements: Analytical Issues. Economic Review of the Federal Reserve Bank of Kansas City, December, 1996.

Shaw, E. S. Financial Deepening in Economic Development. New York: Oxford University Press, 1973.

Shrieves, R. and Dahl, D. The Relationship Between Risk and Capital in Commercial Banks. Journal of Banking and Finance, April 1994, 439-57

Stiglitz, J. E. The Role of the State in Financial Markets. Proceedings of the World Bank Annual Conference on Development Economics 1998, 19-52.

. Knowledge For Development: Economic Science, Economic Policy, and Economic Advise, Address to the World Bank's 10th Annual Bank Conference on Development Economics, 1995. 
Stock, J. H. and Watson, M. W. A Simple Estimator of Cointegrating Vectors in High Order Integrated Systems. Econometrica, July 1993, 783-820.

Wall, L. D. and Peterson, P. Bank's Responses to Binding Regulatory Capital Requirements. Federal Reserve Bank of Atlanta Economic Review, 1996.

Welsh, J., ed. The Regulation of Banks in the Member States of the EEC. London: The Hague, 1991.

Williamson, J. and Mahar, M. A Survey of Financial Liberalisation. Essays in International Finance. Princeton, NJ: Princeton University Press, 1998.

World Bank. The East Asian Miracle: Economic Growth and Public Policy. New York: Oxford University Press, 1993.

Zellner, A. Estimates for Seemingly Unrelated Regression Equations: Some Exact Finite Results. Journal of the American Statistical Association, 1993, 977-92. 